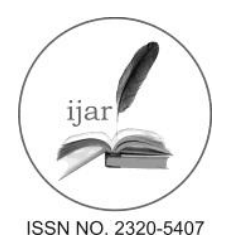

Journal homepage:http://www.journalijar.com

Journal DOI:10.21474/IJAR01

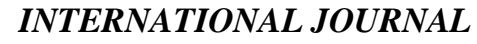

OF ADVANCED RESEARCH

RESEARCH ARTICLE

\title{
AN ANATOMICAL EXPLANATION OF SAMHITOKT " BEEJ BHAGAVAYAV JANYA \& DOHRIDOPCHAR JANYA GARBHAJ VIKARITIYAN" W.S.R.TO TERATOLOGY.
}

\author{
Dr Ashok kr Sharma ${ }^{1}$, Dr Manisha ${ }^{2}$. \\ 1. Lecturer, sharer rachana, A \& U Tibbia college \& hospital karol bagh new delhi-05 \\ 2. M.O.(Ayu.),CH.Brahm.prakash Ayurvedic charak sansthan kheradaber najafgarh new delhi.
}

\section{Manuscript Info}

Manuscript History:

Received: 17 March 2016

Final Accepted: 29 April 2016

Published Online: May 2016

Key words:

BeejBhagavyav,Garbhajvikritiyan,

Dauhridavastha,Bandhya,Putipraja,

Varta,Trinputrik,Teratology

*Corresponding Author

Dr Ashok kr Sharma.

\section{Abstract}

As it is well known to each \& every person that Ayurveda is pioneer medical system having complete status of life science as well as wellness of diseases. Ayurveda has unquestionable scientific veracity, rich vocabulary of diseases, causes, symptoms \& signs and eternal vibrant innovation for modifications. In ancient time the Beej( Sperm\& ova ),BeejBhag (Chromosomes) Beej Bhagavayav $^{1}$ (genes ) was the indication for the hereditary .

Acharya charak has indicated to the vitiation of the organ due to the vitiation of beejbhagavyav which is responsible for formation of that organ.

Here Acharya indicate to the particular contents which are responsible to form particular organelles of fetus body due to deformity of those contents fetus shows abnormality.

"TasmatUbhyorapyatra " means organs with deformity develops due to only the deformity of Beej or BeejBhagavayav. Otherwise any parental deformity dosent transfer to offspring's. Here Acharya indicates directly to the hereditary factors like chromosomes \& genes.

These are oftwo type" VikritArtavPrabhav " or Strivyapad²-Bandhyan (due to deformity in Ova),Putiprijan(due to deformity in Chromosomes of Ova) ,Vartan (deformity in genes situated on X chromosomes)Eg.-- XO Turner Syndrome, XXX Super female.

Purushvyapad- ${ }^{3}$ Bandhyan( Deformity in sperm ), Putiprijan ( Deformity in chromosomes of sperm ), TrinputrikanEg. -- XXY( Klinefelter's Syndrome ).

According to AcharyaSushruta ${ }^{4}$ vitiatedvatadosha or non fulfillmentof maternal desires during dohrdavstha can develop in the fetus a hump ,defective arm or defective leg or he is dumb or has an indistinct speech.

\section{Introduction:-}

it is well known that trait of parents transfer to the offspring via genes as per heredity. in ancient first of all, AcharyaCharak has elaborate this concept in Khuddika Garbhav kranti Sharir.

Mendel has proove the heredity science by experiment in pea plants by seeing the traits transferring into offspring.

\section{Beej bhagavayav janyavi kritiayan and their interpretation with teratology.}

Teratology is the science where the deformities of fetus is studied, in Ayurveda SushrutSharir different type of abnormal shape of fetus is mentioned eg. serpents ${ }^{5}$, scorpions or gourd shaped to women should be considered as the outcome of shameful act by people. 
Beej means sperm and ovum, Beej- Bhagavyav means the part of the ova and sperm which is responsible for the formation of organs of the fetus.

Generally the characteristics into the offspring's come same to the parents because of the BeejBhagavyava, but if it get vitiated then abnormal characteristics can be seen into the child's which is the Ayurvedic theme of teratology.

Major causes given by AcharyaSushrut for fetal anomalies are vat dosh prakopa\& unfulfilled willings of dohridya like- kubs( band or twist), Kuni ( Lula), Pangu ( Langada) Minmin ( Not clearing voice ) .

\section{Material and method:-}

This is a literature review article on genetics found in Ayurveda and its similarity or dissimilarity with the genetics of modern medical science.

Ayurvedic review-there are many diseases described by AcharyaCharak, Sushrut, Vagbhatta, which indicates to the genetics in ayurveda like-sahajprameha,sahajarsha, yonivapad, bandhya, varta, trinputrik ,narshand, narishand etc.

In our texts garbhajvikritiyan are also described, some shapes those are different from the normal shape of fetus like -shape of serpent,scorpion, gourd etc.these all deformities indicates to the teratology present in Aurveda.

\section{Modern review:-}

\section{Some relatedTeratological disorders ${ }^{6}:-$}

Anencephaly:- Cranial Neural fold's fail to elevate and fuse, leaving the cranial neuropore open. The skull never forms, and brain tissue degenerates.

Meningocele:-protrusion of the membranes that cover the spine and part of the spinal cord through the bone defect.

\section{Craniosynostosis:-}

* Scaphocephaly- early closure of sagittal suture

* Brachycephaly- Early closure of coronal\&lambdoid suture

Digital defects:-This is autosomal deformity occurs to the fetus in which, number of the digits or the number of the phalanges varies .

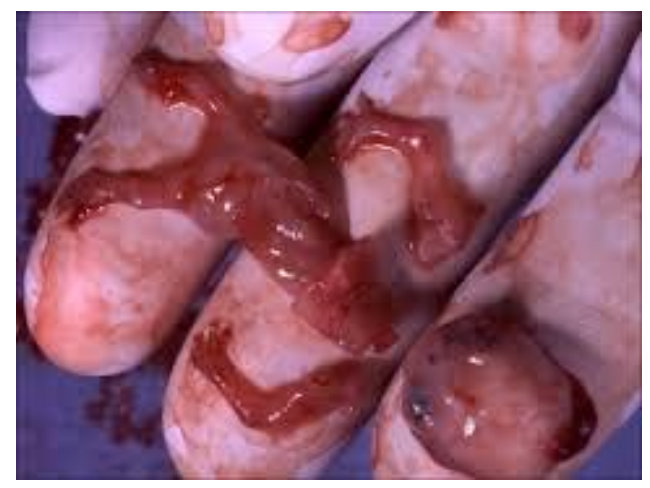

Prune belly syndrome:-A distended abdomen from atrophy of abdominal wallmusculature.

Ectopia cordis:-Ventral body wall defect in thoracic region. There is cleft sternum, and the heart protrudes through defects.

Syn-thorex 


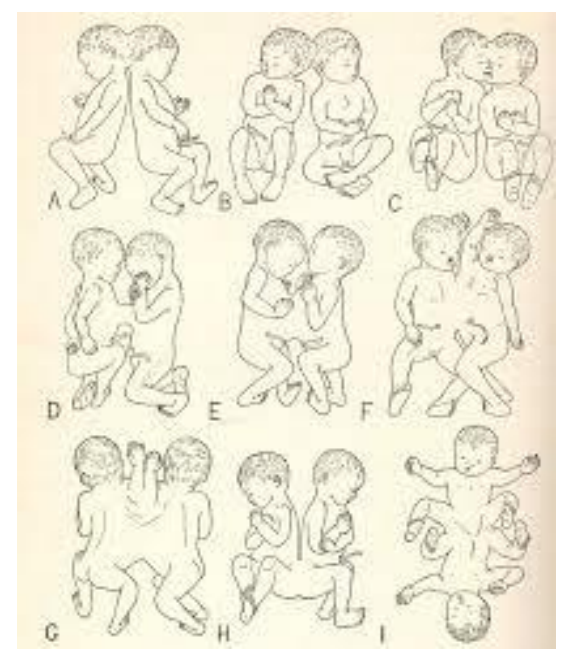

Fig-a,b ,c,d

Bladder Exstrophy caused by a failure of body wall closure in the pelvic region.

Turner syndrome (45x)

Female Psudohermaphrodism

Cleft lip / pallet

Holoprosencephaly - synopthalmia.

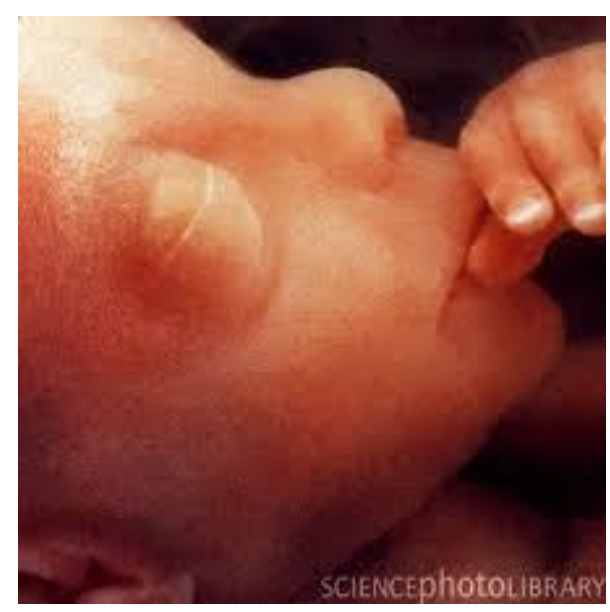

Spina bifida cystica - Involving several vertebra in the lumbosacral region.

Fetus with anencephaly and craniorachischisis .

\section{Interpretation of Autosomal Abnormalities and BeejBhagJamyaVikritian:-}

* Down's Syndrome ( Mongolism ) - Trisomy - 11

* (a) Non Familiar Mongolism 47- chromosomes ( triplo - 21 )

* (b) Familiar Mongolism - 46 chromosomes

- Philadelphia chromosomes - Long Arm of 22 get deleted, attached to another chromosomes.

* Albinism ( absent of enzyme tyrosinase )

* Cat's cry Syndrome - delation in short arm of chromosome $-5^{\text {th }}$.

* Prader 's - Willi Syndrome - Microdelation in long arm of chromosome - 15, derived from father.

* Happy Puppet Syndrome - Microdelation in long arm pf chromosome - 15, drived from mother.

* Robert sonian translocation - between longarm of 13 \& 14 chromosome.

* Siamese twins \& fraternal twins. 


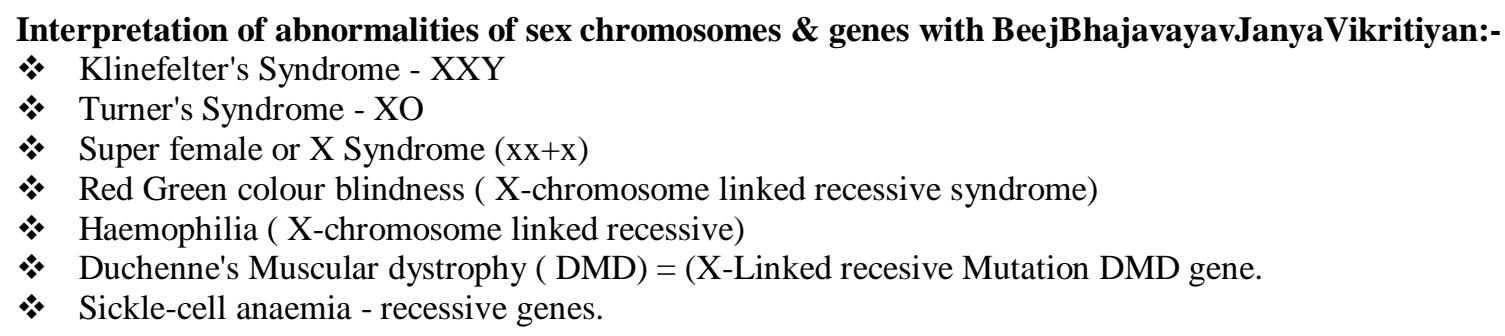

DohridyaAvamanita- for this Ayurvedic texts say's that during the development of fetal at the 3rd or 4th month. mother has some special requirements of "Ahar and Vihar". Avoidness of required things is called "DohridAvamanita" and it is cause of releted fetal anomalies.

DOHRID $^{7}$ (BI-cardiac condition)-there are some sign and symptoms like stoppage of menstruation ,excessive salivation, loss of appetite, vomiting, anorexia, liking taking sour things etc.

If longings is very strong, then even thing which are harmful can be given by neutralizing their injuries effects through processing's or adding wholesome things. this is a necessary with a view to satisfying the desires .by the suppression of the longings the vatadosha get vitiated moves the inside body, and destroys or deforms the the fetus in the formative stage

At the time sense organs develops, fetus shows some impulses, heart starts pulsations then some requirements are shown by fetus through mother is termed Dohirid.

Now a days this statement has come to attention as diet maintenance of pregnant lady so that healthy offspring can be produce.

Acharya Sushrut has indicated some willings and offsprings Accordingly ${ }^{8}$

\begin{tabular}{|l|l|}
\hline \multicolumn{1}{|c|}{ Longings during dauhridavastha } & Effects on offspring's \\
\hline Seeing of king & Rich \&holds high position \\
\hline Fine silk clothes, ornaments & Handsome child of aesthetic taste \\
\hline Visit to hermitage & Child shall pious \&self controlled \\
\hline See a divine idol & Child respected in society \\
\hline See ferocious animal & Child having faith in violence \\
\hline Eating meat of godha (iguna) & sleepy \&drowsy in nature, high memory \\
\hline Eating beef meat & Strong, bear any amount of fatigue, pain \\
\hline Eating buffalo meat & Heroic, red eyes, excessive hairs, \\
\hline Eating bear meat & Drowsy child though vailent, \\
\hline Longing for venion & Energetic, determined \&wandering habit child \\
\hline Eating srmara meat & Unsteady mind, destructive person \\
\hline Titters meat & Timid disposition, cowardly \\
\hline
\end{tabular}

\section{Discussion:-}

It has been observed that our ancient Acharyas were very well known regarding " Beej, Beejbhagavayavjanya " hereditary diseases and disorder. It seems that all above said disorders are already existing in ancient times.

AcharyaSushrut has mentioned all teratological diseases in two types.

" AdiBal Pravrit" " Hereditary disease, " JanamBalPravrit " congenital disease .All above said diseases are described in " Asadhya " disease.

More research should be done in this regard for the ailing humanity.

The oldest system of well beingAyurveda, is having all the Mysteries to which Modern Medical Science is trying to open now a days.

AcharyaCharak has indicated as Incurable those diseases which occur due to " Beejdosha ${ }^{10}$ eg :-prameh ,kusth etc. 
some other deformities related to foetal development according to our textare:- " Nagaudar " " Upvistak " \& " Leengarbh " occurs due to " VikritgarbhiniParicharya".

All the twins like - Siamese twin, fraternal are the foetal developmentdeformities releted to BheejBhagavayaJanyavikritiyanAcharya Mentioned them deform shape like- scorpion, snake etc.

somefoetal anomalies like trinputrik resembles to the kilnfelter syndrome which shows individual male but in fact not perfect because it having abnormal XXY Genome.

Similalarly in the case of varta individual shows female characteristics but in fact not a complete female because it having XO/XXX Genome.

There are two type of foetal anomalies one is of genetic and another are due to autosomal .genetic type anomalies can be considered as "Beejbhagavyavjanyagarbhajvikritiyan".

Teratogens can produce both type of foetal anomalies which are included in aharviharjanyaevmdauhridapcharjanyagarbhajvikritiyan according to ayurveda.

modern science also says this thing if the requirements of a pregnant lady is not fulfilled it can cause harmful to the developing fetus, that's why maintained diet is suggested .

\section{Conclusion:-}

Our texts are rich of all the newely research related diseases in brief. Our Acharyas have included all the teratogenslike Thalidomide, X-rays, Infectious Agents, Hormones in " VikritgarbhiniAharvihar " which can cause fetal anomalies.

Theme of our science " Beej\&BeejbhagavayavJanyaVikritiayan " fits very well to hereditary \& congenital disease and it should be elaborated further.

In ancient era the concept of heredity and the fetus anomalies was present with a clear explanation which fit in modern medical sciences theme.

Different type of abnormal fetus shapes mentioned by AcharyaSushrutes serpents, scorpions, gourds etc. indicates different types of monsters shows ancient teratology.

It seems that in ancient \& in modern era the concept was near about same only way of expression was different.

\section{References:-}

1. Agnivesh,Charak,Dridbal,Charaksamhita,sharir-sthan,khuddikagarbhavkranti 3/17,translated by R.K Sharma \&Bhagwan dash,2nd ed.vol.5,chaukhamba Sanskrit series office Varanasi 2005,pg383.

2. Agnivesh,Charak,Dridbal,Charaksamhita,sharir-sthan,mahatigarbhavkranti 4/30,translated by R.K Sharma \&Bhagwan dash,2nd ed.vol.5,chaukhamba Sanskrit series office Varanasi 2005,pg402.

3. Agnivesh,Charak,Dridbal,Charaksamhita,sharir-sthan,mahatigarbhavkranti 4/31,translated by R.K Sharma \&Bhagwan dash,2nd ed.vol.5, chaukhamba Sanskrit series office Varanasi 2005,pg404

4. VriddSushrut ,Susrut ,Sushrutsamhita,sharirsthan ,sukrasonitsuddhi sharir,2/54,translated by D.G. Thatte,2nded2005, chaukhamba orientaliya delhi,pg39

5. VriddSushrut ,Susrut ,Sushrutsamhita,sharirsthan ,sukrasonitsuddhi sharir,2/53, translated by D.G. Thatte,2nded2005, chaukhamba orientaliya delhi,pg38

6. Inderbeersingh\&G P Pal,Human embryology,8thed2007,ch 14,pg208

7. Agnivesh,Charak,Dridbal,Charaksamhita,sharir-sthan,mahatigarbhavkranti 4/16,translated by R.K Sharma \&Bhagwan dash,2nd ed.vol.5,chaukhamba Sanskrit series office Varanasi 2005,pg396

8. VriddSushrut ,Susrut ,Sushrutsamhita,sharirsthan ,garbhavkrantisharir sharir,3/19-26,translated by D.G. Thatte,2nded2005,chaukhamba orientaliya delhi,pg54

9. VriddSushrut ,Susrut ,Sushrutsamhita,chikitsasthan ,sukrasonitsuddhi sharir,2/53,translated by D.G. Thatte,2nded2005, chaukhamba orientaliya delhi,pg38

10. Agnivesh,Charak,Dridbal,Charaksamhita,chikitsa-sthan, 6/57,translated by R.K Sharma \&Bhagwan dash,2nd ed.vol.5,chaukhamba Sanskrit series office Varanasi 2005. 